\title{
Dietary Iron Intake in Nigeria
}

\author{
Oluwatoyin B Oluwole* and Adebukola A Agboola \\ Food Technology Department, Federal Institute of Industrial Research, Nigeria
}

*Corresponding author: Oluwatoyin B Oluwole, Food Technology Department, Federal Institute of Industrial Research, 1, FIIRO Road, Cappa Busstop, Oshodi, Lagos Nigeria

Submission: October 17, 2017; Published: April 11, 2018

\begin{abstract}
Iron is the second most abundant element on earth, and in diets, it is an essential micronutrient necessary for major functions in the body such as transport of oxygen, synthesis of deoxyribonucleic acid (DNA) and generation of energy from macronutrients through aerobic respiration. Iron deficiency has been documented as the commonest cause of nutritional anaemia globally. In Nigeria, prevalence of iron deficiency anaemia (IDA) among children $<5$ years old has been reported as $22.3 \%$. IDA is associated with negative outcomes such as permanent behavioural and cognitive impairments. Early detection, prompt treatment and outright prevention are necessary to combat these adverse outcomes. This review discusses iron - its human requirements, metabolism and impacts on health. It then focuses on iron status in the Nigerian population, with particular reference to women and children; the strategies to combat iron deficiency are also discussed.
\end{abstract}

Keywords : Iron; Iron deficiency; Anaemia; Food-based interventions; Supplementation; Fortification; Biofortification

Abbreviations : DNA: Deoxyribonucleic Acid; IDA: Iron Deficiency Anaemia; WHO: World Health Organization; RDA: Recommended Daily Allowance; DMT 1: Divalent Metal Transporter 1; HCC: Hepato Cellular Carcinoma; NFCS: Nigeria Food Consumption Survey ; DALYs: Disability-Adjusted Life Years; DRI: Daily Reference Intake

\section{Introduction}

Iron is an important mineral nutrient necessary for the synthesis of haemoglobin and enzymes such as haeme enzymes in the body [1]. Iron is also necessary for the formation of myoglobin, which is the oxygen carrying pigment in the muscle cell, thus, Iron is necessary for the transport of oxygen round the body [2]. Food sources rich in Iron include meat, whole grain cereals, liver, fish, green leafy vegetables, nuts and pulses.

\section{Iron requirements in human beings}

Table 1: Recommended daily allowance (rda) of iron for healthy individuals Iom/Fnb 2001.

\begin{tabular}{|c|c|c|c|c|}
\hline Age & Male (mg) & $\begin{array}{c}\text { Female } \\
\text { (mg) }\end{array}$ & $\begin{array}{c}\text { Pregnancy } \\
\text { (mg) }\end{array}$ & $\begin{array}{c}\text { Lactation } \\
\text { (mg) }\end{array}$ \\
\hline $\begin{array}{c}\text { Birth to 6 } \\
\text { months }\end{array}$ & 0.27 & 0.27 & & \\
\hline 7-12 months & 11 & 11 & & \\
\hline 1-3 years & 7 & 7 & & \\
\hline 4-8 years & 10 & 10 & & \\
\hline 9-13 years & 8 & 8 & & 10 \\
\hline 14-18 years & 11 & 15 & 27 & 9 \\
\hline 19-50 years & 8 & 18 & 27 & \\
\hline 51+ years & 8 & 8 & & \\
\hline
\end{tabular}

The first requirements for iron in humans are met adequately by the breast-milk, however, human needs for iron increases remarkably after $4-6$ months of birth to about $0.7-0.9 \mathrm{mg} /$ day [3]. The Daily Reference Intake (DRI) provides recommendations for intake of iron and other nutrients. The DRI refers to a set of values used for planning and assessing nutrient intakes of healthy people [4]. These values, one of which is the Recommended Daily Allowance (RDA), vary by age and gender. The RDA is an average daily level of intake sufficient to meet the nutrient requirements of nearly all (97\% - 98\%) healthy individuals [4]. Below Table 1 lists the RDA of iron for healthy individuals.

\section{Iron metabolism}

Forms, absorption and bioavailability: There are two forms of dietary iron, haeme and non-haeme [5]. Haeme iron are primarily sourced from haemoglobin and myoglobin obtained from consuming foods such as meat, poultry and fish; non-haeme however is sourced from milk, eggs, legumes, pulses, cereals, fruits and vegetables. Only a fraction of the ingested iron is available for absorption by the body and this depends on the type of iron consumed [6]. The bioavailability of haeme iron is high (15\%-35\%), with other dietary factors having little effect on its absorption [7]; however, non-haeme iron are less bio-available (2\%-20\%) and its absorption is highly affected by other dietary factors [5]. Below Figure 1 shows a simple iron absorption pathway. 


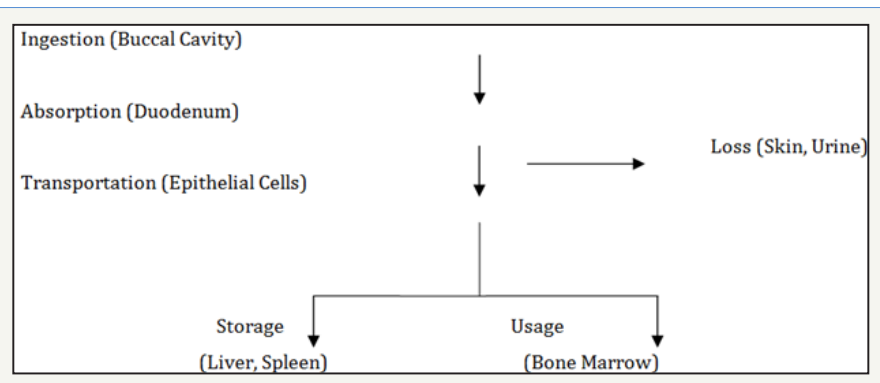

Figure 1: Simple iron absorption pathway.

Iron absorption takes place in the duodenum and upper jejunum [8]. As described by Abbaspour et al. [2], Divalent Metal Transporter 1 (DMT 1) helps with the transfer of iron across epithelial cells. Iron within the enterocyte is released into the bloodstream via ferroportin (a transmembrane protein that exports iron from cells); the glycoprotein, transferring and then binds the iron in the bloodstream from where it is transported to the cells or bone marrow for erythropoiesis - the production of red blood cells [9]. Iron absorption in the duodenum is greatly influenced by the physical state of the iron entering the duodenum. At the physiological $\mathrm{pH}$ of 7.4 , ferrous iron $\left(\mathrm{Fe}^{+2}\right)$ is rapidly oxidised to the insoluble ferric form $\left(\mathrm{Fe}^{+3}\right)$. The $\mathrm{pH}$ of the proximal duodenum is however lower due to the presence of gastric acid, this in turn reduces $\mathrm{Fe}+3$ in the intestinal lumen by ferric reductases. This reduction allows the transport of $\mathrm{Fe}^{+2}$ across the apical membrane of enterocytes and this process enhance the solubility and uptake of ferric iron [10]. Absorbed iron is mostly used by the bone marrow for erythropoiesis [11].

Consuming vitamin $\mathrm{C}$ rich foods such as fruits can significantly increase the absorption and assimilation of non-haeme iron by the body [12]. Also, eating sources of haeme iron such as fish, chicken, liver and meat alongside non-haeme iron foods can help increase the absorption of non-haeme iron body [5]. Food sources that inhibit the absorption of iron include tannins found in coffee and tea, phytic acid, polyphenols, calcium and peptides obtained from partially digested protein. Despite its low bioavailability, nonhaeme iron contributes more to iron nutrition than haeme iron because the quantity of non-haeme iron is usually more than that of haeme iron in most people's meals [13] (Table 2).

Table 2: factors that could influence iron absorption Abbaspour et al. [2].

\begin{tabular}{|c|c|}
\hline Physical State (bioavailability) & $\mathbf{H e m e}>\mathbf{F e}^{+2}>\mathbf{F e}^{+3}$ \\
\hline Inhibitors & $\begin{array}{c}\text { Phytates, polyphenols, calcium, } \\
\text { some proteins }\end{array}$ \\
\hline Competitors; I animal studies & $\begin{array}{c}\text { Lead, cobalt, strontium, } \\
\text { manganese, zinc }\end{array}$ \\
\hline Facilitators & $\begin{array}{c}\text { Ascorbate, citrate, some amino } \\
\text { acids, meat, fish, poultry }\end{array}$ \\
\hline
\end{tabular}

\section{Iron storage, regulation and loss in the body}

The iron content stored by an average adult in the body is about 1 - 3 grams. Iron is stored in insoluble forms in the liver, spleen and bone marrow [14]. Most of the Iron in the body is usually bound to the iron-binding protein-Ferritin [9]. About $10-20 \%$ of the absorbed iron also goes into a storage pool which is also later recycled for erythropoiesis. In the laboratory, testing for serum ferritin concentration is the most convenient way to estimate iron levels in the body as serum ferritin concentrations correlates well with total iron stores in the body under stable conditions [15].

Iron homeostasis is regulated at the point of absorption as there is no defined mechanism for excretion of iron from the body [16]. Hepcidine, a circulating hormone produced by the liver, plays an important role in the regulation of iron homeostasis. Hepcidine binds to ferroportin, macrophages and cells of the placenta; this binding results in the degradation of ferroportin from the cell surface. This in turn leads to a decrease in the absorption of dietary iron and also a decrease in the release of recycled iron from macrophage stores $[16,17]$. Studies from mouse models show that lack of hepcidine expression in the mice studied led to iron overload, while over-expression of hepcidine in the mice led to iron deficiency anaemia - IDA [16]. The production of hepcidine by the liver is however regulated in response to various physiological stimuli. The expression of hepcidine is induced by iron loading, leading to a limit in iron uptake from the diet, while the expression of hepcidine is repressed by anaemia and hypoxia, leading to increased iron availability for erythropoiesis [16,18]. Inflammations due to disease conditions can also increase hepcidine level in the body [18].

Iron is lost daily from the body due to basal losses and other factors. Basal losses include losses through the skin, urine and stool this account for about $1 \mathrm{mg}$ of iron loss per day [19]. Premenopausal women also lose about $2 \mathrm{mg}$ of iron daily during menstruation [20]. Adequate dietary intake is therefore required to replace the iron lost and maintain optimal iron balance in the body.

\section{Iron deficiency and overload}

Iron overload is caused by excessive deposition of iron in the organs and tissues of the body. This result in a condition known as haemochromatosis [21]; haemochromatosis can in turn lead to Hepato Cellular Carcinoma (HCC), liver damage and death [22]. The main mechanism of liver injury in haemochromatosis is through oxidative stress, which involves the production of iron catalysed oxyradicals [23]. Conditions such as high alcohol intake increases ox radicals, and as such, may accelerate the development of liver failure in patients with haemochromatosis [24]. In the presence of anaemia, iron overload is usually caused by multiple blood transfusions.

On the other hand, Iron deficiency is defined as "a condition in which there are no mobilisable iron stores and in which signs of a compromised supply of iron to tissues, including the erythron, are noted" [25]. Iron deficiency occurs when metabolic demands for sustenance of growth and replacement of iron loss, primarily through blood loss, outweighs absorption of iron. This results in depletion of iron stores in the body [14]. Primary causes of iron deficiency include increased requirements during pregnancy, infancy and menstruation; low intake of bio-available iron; and 
excessive blood loss from pathological infections such as helminths infection [26]. There is also the case of physiological requirements not being met by absorption from diet, this result in nutritional iron deficiency [27]. Groups at risk of iron deficiency include children and adolescents, due to growth; women of reproductive age, due to menstruation and pregnancy; frequent blood donors and people with cancer [28-31]. Post menopausal women and adult men are usually at low risk of iron deficiency as their dietary intake can normally cover for their iron requirements. Out of the 10 preventable risks for diseases, disability and death, that altogether account for $40 \%$ of the 56 million annual global deaths, iron deficiency is ranked $7^{\text {th }}$; Iron deficiency is estimated to affect 2 billion people worldwide, with most of them living in developing countries [32].

Iron deficiency can exist with or without anaemia [2]. Iron deficiency anaemia (IDA) occurs when Iron intake is limited or inadequate due to poor diets. Stomach ulcers and other forms of slow, chronic bleeding, for example, haemorrhoids can also lead to iron deficiency anaemia [33]. IDA reduces physical activity and decreases individual work performance because of reduced transportation of oxygen from lungs to the tissues [34]. IDA has huge impacts on national economy in countries where the burden of the disease is high; this is because IDA reduces productivity and earnings and also because the cost of intervention could be high [35]. IDA, co-existing with other forms of malnutrition, is one of the leading causes of morbidity and mortality in children. IDA among children reduces cognitive ability, increases risk of childhood illnesses and reduces physical activity [36]. Among reproductive women, IDA increases the risk of pregnancy complications, resulting in some negative outcomes like premature birth and low birth weight [37]. IDA is estimated to affect about 1.62 billion people worldwide [7].

\section{Elemental iron: uses and health implications}

The earth's crust contains about 5\% iron, making it the second most abundant metal in the crust [38]. However, iron does not usually occur as a free element in nature. Rather, it is usually found in its combined forms as oxides, hydroxides, carbonates and sulphides [39]. The most common form is the oxides, which is formed when iron combines with oxygen in the presence of moist air. The resulting ore, iron oxide, is also known as rust. Compounds of iron are found in the ferric or ferrous forms. Compounds such as ferric phosphates are used as food additives, while ferrous gluconates are used as dietary supplements. Ferric chloride and ferrous sulphate are used for water treatment and purification. Iron can also be combined with carbon and other metals to produce steel which is usually used in construction of materials such as water pipes, cooking pots, and tableware.

Anaerobic ground water, when directly fetched from a well, may contain iron in concentrations as high as $0.5-10 \mathrm{mg} / \mathrm{litre}$; drinking from such water has not been shown to be hazardous to human health [38]. However, for community pipe-borne water, iron concentrations are usually kept below $0.3 \mathrm{mg} / \mathrm{litre}$. Where iron pipes are used for distribution however, at concentrations above $0.05-0.1 \mathrm{mg} /$ litre, water discolouration from rusted iron pipes may start to occur and at concentrations above $0.3 \mathrm{mg} /$ litre, the water will start to taste metallic [38]. Such water may also contain sediments. These sediments have been shown to contain impurities and harbour bacteria. Iron bacteria produce brown, slimy coats in water distribution pipes and they can be harmful to human health [40]. Small amounts of iron can also be ingested from cooking with iron pots. Ingestion of iron from these non-food sources can be beneficial to human health in that it adds small amounts of iron to the diet and can help alleviate some iron deficiency symptoms [41]. However, these should not be depended on as the main iron source for the body.

\section{Iron Status in Nigeria}

Iron deficiency is among the leading micronutrient deficiency in Nigeria. Few studies are however available on the current iron status of the country. The Nigeria Food Consumption Survey (NFCS) conducted in 2003, which highlights the prevalence of iron deficiency among different age groups and different geographical regions in Nigeria, has been shown to be the only nationally representative survey providing data on the prevalence of iron deficiency in Nigeria. Based on serum ferritin concentrations, iron deficiency in Nigeria was determined in the NFCS using the cut-off values given in the (Table 3) [42].

Table 3: Cut-off values for determining iron deficiency Maziya-Dixon et al. [42].

\begin{tabular}{|c|c|}
\hline Serum Ferritin Level $(\mathbf{n g} / \mathbf{m l})$ & Iron Status \\
\hline$<10(0-15$ years $)$ & Iron deficiency \\
\hline$<12(16-74$ years $)$ & Iron deficiency \\
\hline$<20$ & Iron store depletion \\
\hline $20-100$ & Normal range \\
\hline $101-300$ & Slightly above normal \\
\hline$>300$ & Iron overload \\
\hline
\end{tabular}

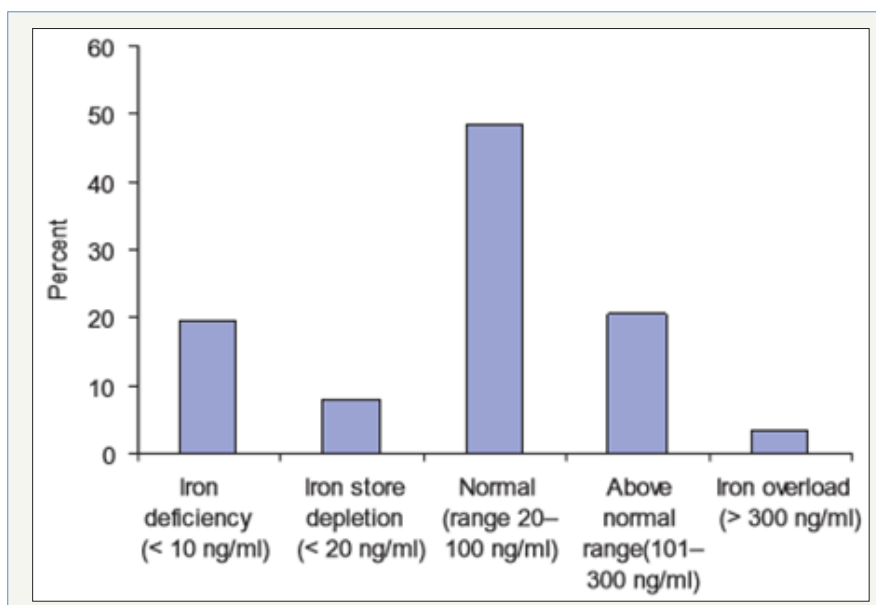

Figure 2 : Profile of national iron stores in children less than 5 years Maziya-Dixon et al. [42]. 
Nationally, $27.5 \%$ of children less than 5 years old were at different stages of iron deficiency. Among these, $8.1 \%$ had a case of depleted iron stores while $19.4 \%$ were iron deficient. (Figure 2) shows the national distribution of the different levels of iron deficiency in children less than 5 years old [42].

Other pockets of studies have been conducted on prevalence of iron deficiency anaemia among children in different communities in Nigeria using haemoglobin concentration tests. A study conducted on children less than 5 years old in Kaduna State, Northern Nigeria by Nnam et al. [43] showed that $22.6 \%$ of the children had mild anaemia, $15.5 \%$ moderate anaemia, and another $15.5 \%$ were severely anaemic. According to Onimawo et al. [44], prevalence of anaemia among school-age children in some selected communities in Abia State, South-East Nigeria was $82.6 \%$, with the rate of mild, moderate to severe anaemia being $9.6 \%, 71.6 \%$ and $1.4 \%$ respectively. The study also showed that all the subjects that were severely anaemic were females. A similar study conducted by Ayogu et al. [45] in Nsukka, Enugu State, South-East Nigeria also revealed a high prevalence of moderate anaemia among the children studied. The below Table 4 shows the specific prevalence of anaemia in different age-groups of children in the study [45].

Inadequate nutrient intake and the presence of parasitic infections in the body have been identified as significant predictors influencing the haemoglobin status of children in Nigeria [46]. In cases where there is adequate nutrient intake, presence of helminths prevents maximum absorption of the necessary nutrients. More than $41 \%$ of the children assessed by [44] were infected with helminths of various types, with hookworm being the most prevalent (13.9\%), followed by roundworm $(10.5 \%)$. This result was corroborated by [45] who reported hookworm (36.7\%) as the most prevalent helminth found in the group of children studied. Other risk factors to IDA as reported include birth order, frequency of illness attacks, household size and skipping of breakfast [45].

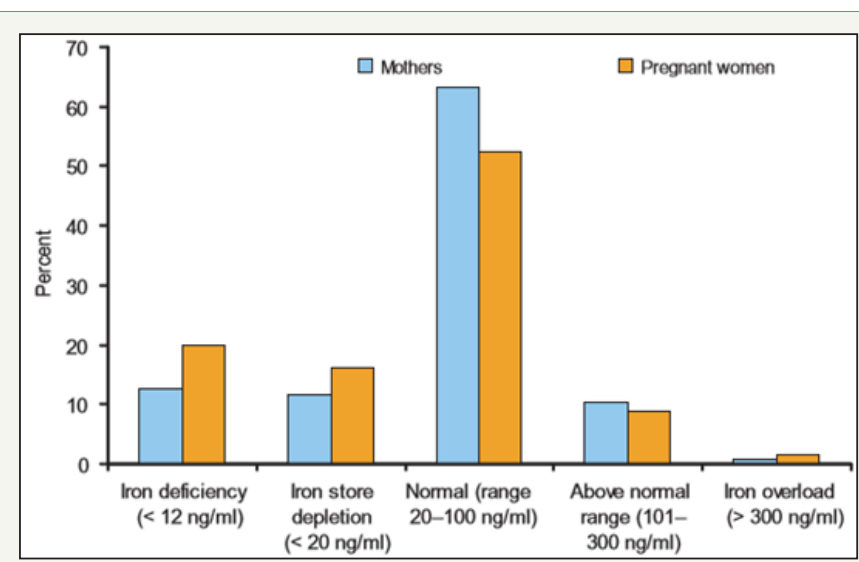

Figure 3 : Profile of national iron status of mothers and pregnant women Maziya-Dixon et al. [42].

Among mothers and pregnant women, the NFCS reported iron deficiency of $12.7 \%$ and $19.9 \%$ respectively [42]; $63.2 \%$ of mothers were within the normal serum ferritin range, while $52.4 \%$ of pregnant women were within the normal ferritin range. Iron overload was more prevalent among pregnant women (1.9\%), compared to non-pregnant women (0.8\%) (Figure 3)[42].

Other studies on prevalence of iron deficiency and anaemia among pregnant women in Nigeria have also been conducted [47]. Reported iron deficiency of 75.6\% among pregnant women in Zaria, Kaduna State, North-Central Nigeria, while among non-pregnant women in the same group, iron deficiency was found to be $25.6 \%$. Among the pregnant subjects, $63.6 \%$ had IDA, while $36.4 \%$ had anaemia due to other causes. This is similar with a study conducted by [48] who reported IDA prevalence of $62.2 \%$ among pregnant women in Rivers State, South-South Nigeria. In Sokoto state, NorthWest Nigeria, [49] reported that IDA prevalence was $21.3 \%$ among pregnant women.

Table 4: Prevalence of anaemia among school-age children by age Ayogu et al. [45].

\begin{tabular}{|c|c|c|c|c|}
\hline Variables & $\begin{array}{c}\text { 6-9 years } \\
N(\%)\end{array}$ & $\begin{array}{c}10-12 \\
\text { years N } \\
(\%)\end{array}$ & $\begin{array}{c}13-15 \\
\text { years N } \\
(\%)\end{array}$ & $\begin{array}{c}\text { Total N } \\
\text { (\%) }\end{array}$ \\
\hline \multicolumn{5}{|c|}{ Haemoglobin (g/dl) } \\
\hline Normal ( $\geq 11.5 / 12.0)$ & $9(28.1)$ & $4(16.0)$ & $0(0.0)$ & $\begin{array}{c}13 \\
(14.5)\end{array}$ \\
\hline $\begin{array}{l}\text { Mild Anaemia (10.0- } \\
11.4)\end{array}$ & $0(0.0)$ & $2(8.0)$ & $11(33.3)$ & $\begin{array}{c}13 \\
(14.5)\end{array}$ \\
\hline $\begin{array}{c}\text { Moderate Anaemia } \\
(7.0-9.9)\end{array}$ & $18(56.3)$ & $16(64.0)$ & $22(66.7)$ & $\begin{array}{c}56 \\
(62.2)\end{array}$ \\
\hline Severe Anaemia $(<7.0)$ & $5(15.6)$ & $3(12.0)$ & $0(0.0)$ & 8. (8.8) \\
\hline Total & $\begin{array}{c}32 \\
(100.0)\end{array}$ & $\begin{array}{c}25 \\
(100.0)\end{array}$ & $\begin{array}{c}33 \\
(100.0)\end{array}$ & $\begin{array}{c}90 \\
(100.0)\end{array}$ \\
\hline
\end{tabular}

In a developing country like Nigeria, the cause of maternal iron deficiency and anaemia In pregnancy are usually multifaceted, with causes ranging from inadequate intake of iron and folate to presence of parasitic infections from helminths and malaria and in addition, human immunodeficiency virus [50].

\section{Interventions for addressing iron deficiency}

As stated earlier, iron deficiency affects billions of people globally, particularly in developing countries, with causes ranging from blood losses during menstruation and child birth to episodes of parasitic infection and other illnesses. Thus, various strategies have been employed to combat this scourge. These include control of parasitic infections through de-worming and iron supplementation, especially during pregnancy. According to the Demography and Health survey conducted in Nigeria in 2013 [51], close to $40 \%$ of all the women in the different age ranges surveyed indicated that they did not take any iron supplement during their last pregnancy, while only $10 \%$ in the different age ranges stated that they took a de-worming medication during their last pregnancy. Statistics such as this goes a long way in showing reasons why prevalence of iron deficiency is still relatively high in Nigeria. More advocacy and health promotion strategies will be needed by the government to combat iron deficiency. 
Other interventions to address iron deficiency include food diversification/nutrition education, iron fortification and bio fortification.

\section{Dietary diversity and nutrition education}

The use of dietary diversification for combating iron deficiency involves promotion of the consumption of iron-rich foods, particularly fleshy foods; promotion of consumption of fruits and vegetables rich in vitamin $\mathrm{C}$ to increase absorption of iron from non-heame sources; and reduction in the consumption of iron absorption inhibiting foods, particularly alongside iron-rich food sources. (Table 4) below shows some Nigerian traditional meals rich in iron. Mothers and care-givers should be educated and encouraged to prepare these iron-rich meals as part of their home cooking. Families can also be educated on owning subsistence farms/home gardens where they can grow iron-rich food crops for their immediate family and rear animals like chicken or goats to supply meat and eggs. In rural Nigeria communities, it is actually not out of place to see such subsistence farms already in place; however, it is often the case that household heads usually sell these food products to raise money for other family needs, which may include paying hospital bills for the treatment of iron-deficiency related illnesses. This is usually as a result of poverty which is almost always the underlying cause of poor dietary choices among this population. It is therefore, imperative that the government should introduce poverty alleviation programmes which would improve the economy of these people while encouraging consumption of products from homestead gardens/farms through public health advocacy and nutrition education in a bid to reduce risk of illnesses due to iron deficiency.

Education on food processing methods that would help make iron easily bio available from consumed foods should also be considered. Such food processing methods include food fermentation and germination techniques and pre-cooking of some vegetables before consumption (Table 4) [52].

\section{Iron fortification}

Iron fortification of basic foods is perhaps the most economical and most convenient strategy to combating micronutrient deficiency, particularly as it does not require consumers to modify their food habits. However, food fortification might as well pose a difficulty when choosing the appropriate iron compound as the fortificant as well as the food vehicle. Iron compounds with high bioavailability are soluble in water and acid but often react with food components to change the organoleptic properties of the food - this may result in consumers rejecting the food [53]. Because of this, less soluble forms of iron, which are also less absorbed, are often used for iron fortification of food to avoid changes in the sensory characteristics. Generally, the factors that need to be considered for an iron fortificant include solubility, interaction with the food vehicle, bioavailability and cost [54].

In Nigeria, the national campaign for fortification of foods started since the 90's. Most of our traditional foods are iron-rich, however a lot of these are lost during food processing and thus, calling for the addition of fortificants to our food sources is necessary. Food products which are being fortified with iron in Nigeria include dairy products, cocoa, cereals and flour, noodles and so on. However, the most common food vehicle for iron fortification in Nigeria is wheat flour. Pockets of producers also fortify rice, but this is not available in large scale-fortifying a product like rice, which is a Nigeria staple, will go a long way in reducing iron deficiency. More government effort is needed in this area, especially as production and consumption of locally made rice is being promoted by the government with the ban on importation of rice.

\section{Biofortification}

According to the World Health Organisation, bio fortification involves increasing the nutritional qualities of food through agronomic practices, conventional plant breeding, or modern technology. With bio fortification, nutrient levels of food are increased during plant growth unlike the conventional fortification in which nutrients are added during food processing. Food crops such as beans, cassava and millet have been successfully bio fortified with iron. According to Nguema et al. [55] iron bio fortified cassava is estimated to reduce disability-adjusted life years (DALYs) lost due to health problems by $6 \%$. In developing countries, bio fortification presents an easier and a more affordable way to reach people living in the rural areas, who are mainly farmers, through agro-extension services like seed-sharing [56-58] (Table 5).

Table 5: Micronutrient-rich traditional nigerian food dishes Okeke et al. [52].

\begin{tabular}{|c|c|c|}
\hline Traditional Soups/Dishes & Description/Composition/Major Ingredients \\
\hline $\begin{array}{c}\text { (Ogbono, equsi, bitter leaf vegetable soups/ } \\
\text { sauces Banga or palm fruit soup })\end{array}$ & $\begin{array}{c}\text { Vegetables, meat/fish, crayfish, pepper, palm-oil, } \\
\text { condiments (melon, dikanut, cocoyam, other soup } \\
\text { thickners })\end{array}$ \\
\hline Ayaraya Oka & $\begin{array}{c}\text { Corn mixed with pigeon pea, vegetables, oil bean, Palm } \\
\text { oil, pepper }\end{array}$ & Iron, $\beta$ Carotene, Zinc \\
\hline Achicha & $\begin{array}{c}\text { Dried Cocoyamin A, Iron, Zinc } \\
\text { oil, green leafy vegetables }\end{array}$ \\
\hline Moimoi & $\begin{array}{c}\text { Wet or dry milled dehulled cowpea paste mixed with } \beta \\
\text { palm oil, pepper, onion crayfish, pices of meat, fish or } \\
\text { egg (optional), steamed into a pudding }\end{array}$ & Iron, Zinc, $\beta$ Carotene, folate, copper \\
\hline
\end{tabular}




\begin{tabular}{|c|c|c|}
\hline Akara & $\begin{array}{l}\text { Wet or dry milled dehulled cowpea paste, whipped } \\
\text { and mixed with pepper, onion, salt and deep fried in } \\
\text { balls in vegetable oil }\end{array}$ & Iron, Zinc \\
\hline Yam Pottage & $\begin{array}{l}\text { Yam cubes boiled with palm of crayfish, fish(optional), } \\
\text { green leafy vegetables }\end{array}$ & Iron, $\beta$ Carotene \\
\hline Ukwa(Afuoka) & $\begin{array}{c}\text { Bradfruit mixed with corn, pieces of fish or meat, } \\
\text { bitterleaf, salt, pepper }\end{array}$ & Iron, Zinc, $\beta$ Carotene \\
\hline Utipiri & $\begin{array}{l}\text { Corn mixed with ugboguru (Pumpkin leaf), oil bean, } \\
\text { and pepper, salt }\end{array}$ & Iron, Zinc, $\beta$ Carotene \\
\hline Bean Pottage & $\begin{array}{c}\text { Cowpea or other legumes mixed with palm oil, salt, } \\
\text { pepper, onion }\end{array}$ & Iron, Zinc, $\beta$ Carotene \\
\hline Okpa & $\begin{array}{l}\text { Bambara ground nut flour paste mixed with palm oil, } \\
\text { pepper, salt and spices(optional) }\end{array}$ & $\begin{array}{c}\text { Protein, iron, niacin, magnesium, } \beta \\
\text { Carotene }\end{array}$ \\
\hline Okpa fufu and soup & $\begin{array}{l}\text { Okpa fufu is a gelatinized dough made from bambara } \\
\text { flour and eaten with traditional soups/sauces }\end{array}$ & Iron, Zinc $\beta$ Carotene \\
\hline Ukpo-ogede & $\begin{array}{l}\text { Dried plantain flour, over ripped plantain paste, palm } \\
\text { oil, pepper salt }\end{array}$ & $\beta$ Carotene, Iron, Zinc \\
\hline Igbangwu-Oka & $\begin{array}{c}\text { Parboiled dried maize wet milled and mixed with palm } \\
\text { oil, pepper, onion, crayfish, fermented oil bean, green } \\
\text { leafy vegetable abd streamed into a pudding. Termites } \\
\text { are added in some area }\end{array}$ & $\beta$ Carotene, Iron, Zinc \\
\hline Native/ local Salads & $\begin{array}{l}\text { Dried cassava slices mixed with palm oil, leaf green } \\
\text { vegetable (Solanum spp. or Gnetum spp.). Dried cassava } \\
\text { slices mixed with fermented oil bean seed slices with } \\
\text { or without leafy green vegetable, palm oil, salt, pepper. } \\
\text { Raw Gnetum spp. Slices mixed with palm oil. Note: } \\
\text { In all the above varieties of salad the palm oil may } \\
\text { be mixed with "trona" (akanwu, in lgbo) or potash to } \\
\text { produce a yellow paste ncha (soap) Also crayfish, pieces } \\
\text { of cow skin (kpomo/kanda) are added }\end{array}$ & $\beta$ Carotene, Iron, Vitamin C, Zinc \\
\hline
\end{tabular}

\section{Conclusion}

Iron is one of the highly important micronutrients. Its deficiency in the body will lead to suboptimal pregnancy outcomes in women, delayed mental and motor development in children, and reduced work capacity with negative impacts on the national economy due to diseases, disability and death. Various strategies are being employed to address iron deficiency; these include iron supplementation, de-worming, dietary diversification, iron fortification and bio fortification of food crops, each with their varying degrees of success. A combination of these strategies, as part of an integrated approach iron deficiency program will definitely go a long way in reducing prevalence of iron deficiency, including IDA, in the Nigerian population. More research is however needed in the development of iron-rich food products, particularly to improve consumption and bioavailability of iron, and in turn reduce negative health outcomes due to iron deficiency, for the benefit of Nigeria and the world at large.

\section{References}

1. Wessling-Resnick M (2014) Iron. In: Ross AC, Caballero B, Cousins RJ, Tucker KL, Ziegler RG (Eds.), Modern nutrition in health and disease. $11^{\text {th }}$ (edn), Lippincott Williams \& Wilkins, Baltimore, Maryland, pp. 176188.

2. Abbaspour N, Hurrell R, Kelishadi R (2014) Review on iron and its importance for human health. J Res Med Sci 19(2): 164-174.

3. FAO/WHO (2004) Expert Consultation on vitamin and mineral requirements in human nutrition: report of joint FAO/WHO expert consultation $\left(2^{\text {nd }}\right.$ edn), Food and Agricultural Organisation Press, Bangkok, Thailand.

4. Institute of Medicine/Food and Nutrition Board $\{$ IOM/FNB $\}$ (2001) Dietary Reference Intakes for Vitamin A, Vitamin K, Arsenic, Boron, Chromium, Copper, Iodine, Iron, Manganese, Molybdenum, Nickel, Silicon, Vanadium, and Zinc: a report of the panel on micronutrients. National Academy Press, Washington, USA.

5. Hurrell R, Egli I (2010) Iron bioavailability and dietary reference values. Am J Clin Nutr 91(5): 1461S-1467S.

6. Mc Dowell LR (2003) Minerals in animal and human nutrition. $2^{\text {nd }}$ edn Elsevier Science, Amsterdam, Netherlands, 660.

7. FAO/WHO (2001) Human vitamin and mineral requirements: Food based approaches to meeting vitamin and mineral needs. Food and Agricultural Organisation Press, Rome, Italy.

8. Muir A, Hopfer U (1985) Regional specificity of iron uptake by small intestinal brush-boarder membranes from normal and iron deficient mice. Am J Physiol 248(3 pt 1): G376-G379.

9. Nadadur SS, Srirama K, Mudipalli A (2008) Iron transport and homeostasis mechanisms: their role in health and disease. Indian J Med Res 128(4): 533-544.

10. Ohgami RS, Campagna DR, Mc Donald A, Fleming MD (2006) The Steap proteins are metalloreductases. Blood 108(4): 1388-1394.

11. Frazer DM, Anderson GJ (2005) Iron imports. I. Intestinal iron absorption and its regulation. Am J Physiol Gastrointest Liver Physiol 289(4): G631-G635.

12. FAO (1997) Agricultural food and nutrition for Africa: a resource book for teachers of agriculture. Food and Agricultural Organisation Press, Rome, Italy. 
13. Monsen ER, Hallberg L, Layrisse M, Hegsted DM, Cook JD, et al. (1978) Estimation of available dietary iron. Am J Clin Nutr 31(1): 134-141.

14. Wood RJ, Ronnenberg A (2005) Iron. In: Shils ME, Shike M, Ross AC, Caballero B, Cousins RJ (Eds.), Modern nutrition in health and disease. $10^{\text {th }}$ edn, Lippincott Williams \& Wilkins, Baltimore, Maryland, pp. 248 270.

15. Hunt JR (2001) How important is dietary iron bioavailability? Am J Clin Nutr 73(1): 3-4.

16. Finberg KE (2011) Unraveling mechanisms regulating systemic iron homeostasis. Hematology Am Soc Hematol Educ Program 1: 532-537.

17. Nemeth E, Tuttle MS, Powelson J, Vaughn MB, Donovan A, et al. (2004) Hepcidin regulates cellular iron efflux by binding to ferroportin and inducing its internalization. Science 306(5704): 2090-2093.

18. Fleming MD (2008) The regulation of hepcidine and its effects on systemic and cellular iron metabolism. Hematology Am Soc Hematol Educ Program 151-158.

19. De Maeyer EM, Dallman P, Gurney JM, Hallberg L, Sood SK, et al. (1989) Preventing and controlling iron deficiency anaemia through primary health care: a guide for health administrators and programme managers. World Health Organization Press, Geneva, Switzerland.

20. Bothwell TH, Charlton RW (1982) A general approach to the problems of iron deficiency and iron overload in the population at large. Semin Hematol 19(1): 54-67.

21. Gangaidzo IT, Gordeuk VR (1995) Hepatocellular carcinoma and African iron overload. Gut 37(5): 727-730.

22. Fargion S, Mandelli C, Piperno A, Cesana B, Fracanzani AL, et al. (1992) Survival and prognostic factors in 212 Italian patients with genetic haemochromatosis. Hepatology 15(4): 655-659.

23. Houglum K, Ramm GA, Crawford DH, Witztum JL, Powell LW, et al. (1997) Excess iron induces hepatic oxidative stress and transforming growth factor $\beta 1$ in genetic hemochromatosis. Hepatology 26: 605-610.

24. Adams P, Agnew S (1996) Alcoholism in hereditary hemochromatosis revisited: prevalence and clinical consequences among homozygous siblings. Hepatology 23(4): 724-727.

25. WHO/UNICEF/UNU (2001) Iron deficiency anaemia assessment, prevention and control. World Health Organization (WHO) Press, Geneva, Switzerland.

26. Crompton DW, Nesheim MC (2002) Nutritional impact of intestinal helminthiasis during the human life cycle. Annu Rev Nutr 22: 35-99.

27. Zimmermann MB, Hurrell RF (2007) Nutritional iron deficiency. Lancet 370(9586): 115-120

28. Black MM, Quigg AM, Hurley KM, Pepper MR (2011) Iron deficiency and iron-deficiency anemia in the first two years of life: strategies to prevent loss of developmental potential. Nutr Rev 69 (S1): S64-S70.

29. Aapro M, Osterborg A, Gascon P, Ludwig H, Beguin Y (2012) Prevalence and management of cancer-related anaemia, iron deficiency and the specific role of i.v. iron. Ann Oncol 23(8): 1954-1962.

30. Napolitano M, Dolce A, Celenza G, Grandone E, Perilli MG, et al. (2014) Iron-dependent erythropoiesis in women with excessive menstrual blood losses and women with normal menses. Ann Haematol 93(3): 557-563.

31. Kiss JE, Brambilla D, Glynn SA, Mast AE, Spencer BR, et al. (2015) Oral iron supplementation after blood donation: a randomized clinical trial. JAMA 313(6): 575-583.

32. Nestel P, Bouic HE, Meenakshi JV, Pfeiffer N (2006) Biofortification of staple food crops. J Nutr 136(4): 1064-1067.

33. Johnson-Wimbley TD, Graham DY (2011) Diagnosis and management of iron deficiency anaemia in the 21st century. Therap Adv Gastroenterol 4(3): 177-184.
34. Clark SF (2008) Iron Deficiency Anaemia. Nutr Clin Pract 23(2): 128141.

35. Horton S, Ross J (2003) The economics of iron deficiency. Food Policy 28(1): 51-75

36. Baker RD, Greer FR (2010) Diagnosis and prevention of iron deficiency and iron-deficiency anaemia in infants and young children (0-3 years of age). Pediatrics 126(5): 1040-1050.

37. Scholl T0 (2011) Maternal iron status: relation to fetal growth, length of gestation, and iron endowment of the neonate. Nutr Rev 69 (S1): S23-S29.

38. WHO (2003) Iron in drinking water: background document for development of WHO guidelines for drinking-water quality. World Health Organisation Press, Geneva, Switzerland.

39. Gurzau ES, Neagu C, Gurzau AE (2003) Essential metals - case study on iron. Ecotoxicol Environ Saf 56(1): 190-200.

40. Vaerewijck MJM, Huys G, Palomino JC, Swings J, Portaels F (2005) Mycobacteria in drinking water distribution systems: ecology and significance for human health. FEMS Microbiol Rev 29(5): 911-934.

41. Tripp K, Mackeith N, Woodruff BA, Talley L, Mselle L, et al. (2010) Acceptability and use of iron and iron-alloy cooking pots: implications for anaemia control programmes. Publ Health Nutr 13(1): 123-130.

42. Maziya-Dixon B, Akinyele IO, Oguntona EB, Nokoe S, Sanusi RA, et al. (2004) Nigeria Food Consumption and Nutrition Survey 2002-2003 Summary. International Institute of Tropical Agriculture Press, Ibadan, Nigeria.

43. Nnam N, Okwori E, Eme P (2015) Iron Status of children aged 6-59 months in Kaduna State of Nigeria. Eur J Nutr Food Saf 5(5): 456

44. Onimawo LA, Ukegbu PO, Asumugha VU, Anyika J, Okudu H, et al. (2010) Assessment of anaemia and iron status of school age children (aged 7-12 years) in rural communities of Abia State, Nigeria. Afr J Food Agric Nutr Dev 10(5): 2570-2586.

45. Ayogu RNB, Okafor AM, Ene-Obong HN (2015) Iron status of schoolchildren (6-15 years) and associated factors in rural Nigeria. Food Nutr Res 59: 26223

46. Jeremiah ZA, Uko EK, Buseri FI, Adias TC (2009) Baseline iron status of apparently healthy children in Port-Harcourt, Nigeria. Eur J Gen Med 6(1): 38-41.

47. Hassan AA, Mamman AI, Adaji S, Musa B, Kene S (2014) Anaemia and iron deficiency in pregnant women in Zaria, Nigeria. Sub-Saharan Afr J Med 1: 36-39.

48. Ndukwu G, Dienye P (2012) Prevalence and socio-demographic factors associated with anaemia in pregnancy in a primary health centre in Rivers State, Nigeria. Afr J Prim Health Care Fam Med 4(1): 328.

49. Erhabor O, Isaac IZ, Isah A, Udomah FP (2013) Iron deficiency anaemia among antenatal women in Sokoto, Nigeria. Brit J Med Health Sci 1(4): 47-57.

50. Vanderjagt DJ, Brock HS, Melah GS, El-Nafaty AU, Crossey MJ, et al. (2007) Nutritional factors associated with anaemia in pregnant women in Northern Nigeria. J Health Popul Nutr 25(1): 75-81.

51. NPC/ICF International (2014) Nigeria Demographic and Health Survey 2013. National Population Commission (NPC) and ICF International, Abuja, Nigeria, and Rockville, Maryland, USA.

52. Okeke EC, Ene-Obong HN, Uzuegbunam AO, Ozioko A, Umeh SI, et al. (2009) The igbo traditional food system documented in four states in southern Nigeria. Food and Agricultural Organisation Press, Rome, Italy.

53. Ebuehi OAT, Oyewole AC (2011) Biochemical studies of iron fortified Nigerian rice fed to phenylhydrazine induced anaemic rats. Am J Biochem Mol Biol 1(2): 168-177. 
54. García-Casal MN, Layrisse M, Solano L, Barón MA, Arguello F, et al. (1998) Vitamin $A$ and $\beta$-carotene can improve non-heme iron absorption from rice, wheat and corn by humans. J Nutr 128(3): 646-650.

55. Nguema A, Norton GW, Fregene M, Sayre R, Manary M (2011) Expected economic benefits of meeting nutritional needs through biofortified cassava in Nigeria and Kenya. Afr J Agric Resour Econ 6(1): 1-17.

56. Muir A, Hopfer U (1985) Regional specificity of iron uptake by small intestinal brush-boarder membranes from normal and iron deficient mice. Am J Physiol 248(3 pt 1): G376-G379.
57. Sayre R, Beeching JR, Cahoon EB, Egesi C, Fauget C, et al. (2011) The biocassava plus program: biofortification of cassava for sub-Saharan Africa. Annu Rev Plant Biol 62: 251-272.

58. WHO (2008) Iron deficiency anaemia: assessment, prevention, and control. A guide for programme managers. World Health Organisation Press, Geneva, Switzerland.

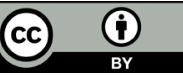

Creative Commons Attribution 4.0 International License

For possible submissions Click Here

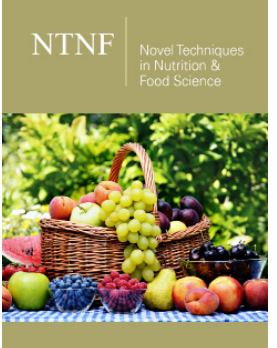

Novel Techniques in Nutrition and Food Science

\section{Benefits of Publishing with us}

- High-level peer review and editorial services

- Freely accessible online immediately upon publication

- Authors retain the copyright to their work

- Licensing it under a Creative Commons license

- Visibility through different online platforms 